\title{
Papuloerythroderma of Ofuji: First Case Report in Portugal
}

\section{Papuloeritrodermia de Ofuji: Primeiro Caso em Portugal}

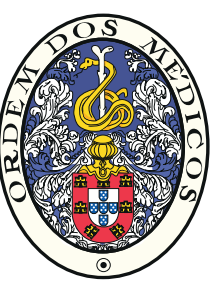

Inês RAPOSO ${ }^{1}{ }^{1}$, Madalena SANCHES ${ }^{1}$, Sandra FERREIRA 1 , Manuela SELORES ${ }^{1,2,3}$

Acta Med Port 2019 Mar;32(3):244-244 - https://doi.org/10.20344/amp.10694

Keywords: Portugal; Skin Diseases, Papulosquamous

Palavras-chave: Dermatopatias Papuloescamosas; Portugal

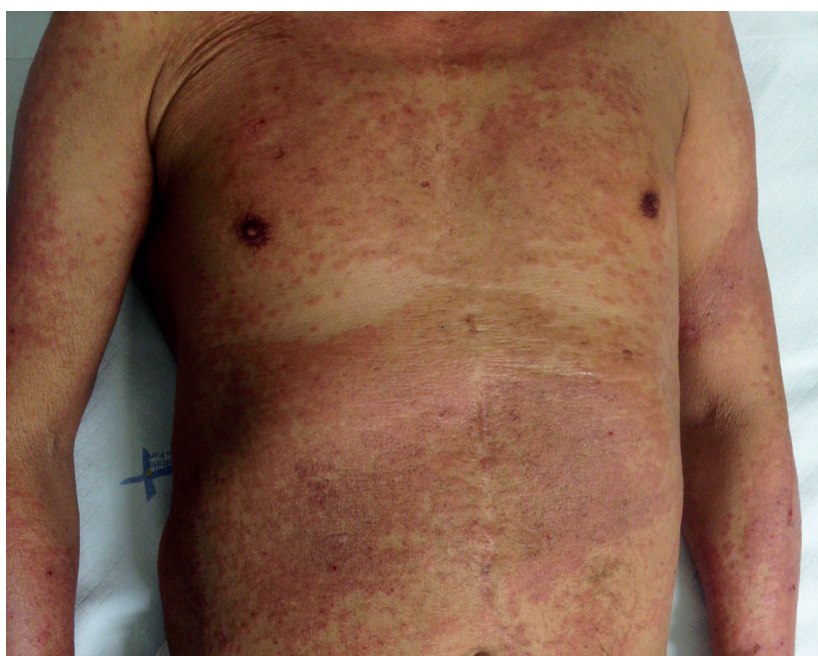

Figure 1 - Clinical aspect of the lesions. Cutaneous eruption sparing all skin folds - deck-chair sign.

A 65-year-old man presented with a pruritic, erythrodermic cutaneous eruption consisting of multiple flat-topped red-brown papules and plaques with a cobblestone appearance, strikingly sparing all skin folds (Figs. 1 and 2). Laboratory results showed peripheral eosinophilia (1.96 $\mathrm{x}$ $\left.10^{3} / \mathrm{uL}\right)$, lymphopenia $\left(0.83 \times 10^{3} / \mathrm{uL}\right)$ and elevated total $\mathrm{lgE}$ (3951 KU/L). Histopathology exhibited perivascular dermal infiltrate of lymphocytes and eosinophils. Cutaneous and peripheral blood cytometry, infectious and age-appropriate cancer screening revealed no changes. No atopy or drug history was identified.

Clinical and laboratory data fulfilled diagnostic criteria of

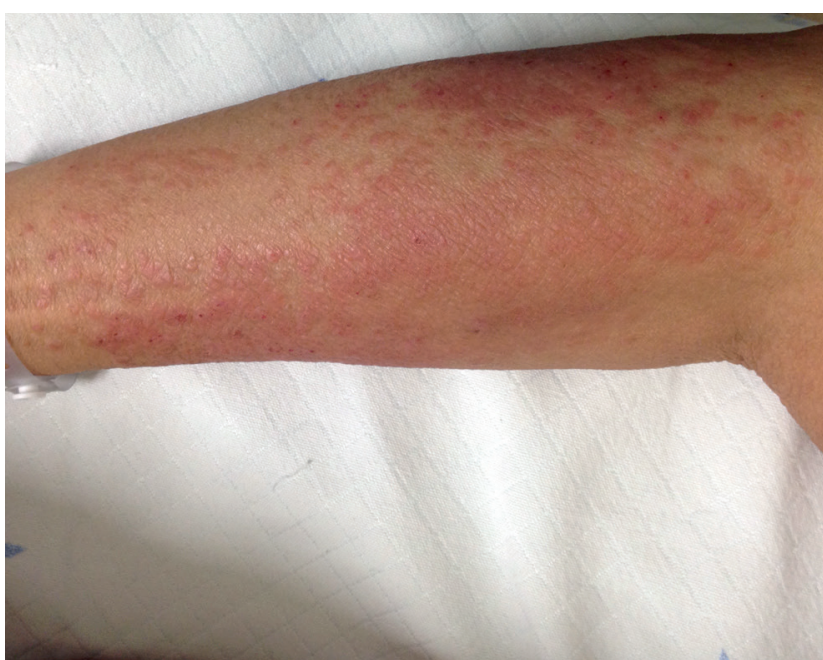

Figure 2 - Cobblestone-like pattern of the cutaneous lesions

primary papuloerythroderma of Ofuji. ${ }^{1}$ The patient initiated PUVA phototherapy, with complete clinical response.

Papuloerythroderma of Ofuji represents a strikingly rare cause of erythroderma. Cutaneous lesions with a characteristic appearance (cobblestone-like) and distribution pattern (uninvolved skin folds - 'deck-chair sign') represent the hallmark of the dermatosis, ${ }^{1,2}$ alongside the frequent association with peripheral eosinophilia, lymphopenia and increased $\operatorname{lgE}$. $^{1,2}$

Most cases have no underlying cause, while exclusion of secondary causes (neoplasms, infections, atopy or drugs) is of prognostic importance..$^{3,4}$

PROTECTION OF HUMANS AND ANIMALS: The authors declare that the procedures were followed according to the regulations established by the Clinical Research and Ethics Committee and to the Helsinki Declaration of the World Medical Association.

DATA CONFIDENTIALITY: The authors declare having followed the protocols in use at their working center regarding patients' data publication. INFORMED CONSENT: Obtained.

CONFLICTS OF INTEREST: All authors report no conflict of interest.

FUNDING SOURCES: This research received no specific grant from any funding agency in the public, commercial, or not-for-profit sectors.

\section{REFERENCES}

1. Torchia D, Miteva M, Hu S, Cohen C, Romanelli P. Papuloerythroderma 2009: two new cases and systematic review of the worldwide literature 25 years after its identification by Ofuji et al. Dermatology. 2010;220:311-20.

2. Bettoli V, Pizzigoni S, Borghi A, Virgili A. Ofuji papulo-erythroderma: a reappraisal of the deck-chair sign. Dermatology. 2004;209:1-4.

3. Maher AM, Ward CE, Glassman S, Litvinov IV. The importance of excluding cutaneous T-cell lymphomas in patients with a working diagnosis of papuloerythroderma of Ofuji: a case series. Case Rep Dermatol. 2018;10:46-54.

4. Otero-Rivas MM, Sanchez-Sambucety P, Gonzalez-Moran A, Rodriguez-Prieto MA. Papuloerythroderma of Ofuji associated with CD3,(+) CD4,(+) and CD8(-) cutaneous T-cell lymphoma and monoclonal gammopathy of undetermined significance. Actas Dermosifiliogr. 2015;106:435-7.

1. Department of Dermatology. Centro Hospitalar do Porto. Porto. Portugal.

2. Instituto de Ciências Biomédicas Abel Salazar. University of Porto. Porto. Portugal.

3. Dermatology Research Unit. Centro Hospitalar do Porto. Porto. Portugal.

$\triangle$ Autor correspondente: Inês Raposo. inesraposovs@gmail.com

Recebido: 20 de abril de 2018 - Aceite: 22 de agosto de 2018 | Copyright $\odot$ Ordem dos Médicos 2019 